\title{
The underestimated role of universities for the Brazilian system of innovation
}

\author{
WILSON SUZIGAN* \\ EDUARDO DA MOTTA E ALBUQUERQUE
}

Conventional wisdom usually underestimates the important role of public research institutes and universities in successful cases of Brazilian economy. History of science and technology institutions shows a long-term process of formation of these institutions and their interactions with industrial firms, agricultural producers or society. This paper investigates historical roots of successful cases of Brazil. First, we present the late onset of National Innovation System (NSI) institutions and waves of institutional formation in Brazil. Second, we describe the history of three selected successful cases, which spans from a low-tech sector (agriculture), a medium-tech sector (steel and special metal alloys), to a high-tech sector (aircraft). These findings present new challenges for present-day developmental policies.

Keywords: interaction between universities and firms; historical roots; science; technology.

JEL Classification: N O3.

\footnotetext{
* Respectively, Instituto de Geociências da UNICAMP-IG/Unicamp. E-mail wsuzigan@ige.unicamp.br; Centro de Desenvolvimento e Planejamento Regional - Cedeplar-UFMG DPCT. E-mail: albuquer@cedeplar.ufmg.br). Paper presented to the XVth World Economic History Congress, session on science, technology and economic history, Utrecht, The Netherlands, August 3-7, 2009 A preliminary version of this paper was presented at the Session on Science, Technology and Economic History, 1er. CLADHE - Latin American Economic History Congress. Montevideo, December 5-7, 2007. The authors are thankful to the session organizers, Tamás Szmrecsányi and Luiz Carlos Soares, as well as to the session participants for many useful comments. Assistance with data and charts by Hérica Righi is also gratefully acknowledged. The research from which this paper originated is supported by $\mathrm{CNPq}-\mathrm{National}$ Council for Scientific and Technological Development (Process no. 401666/2006-9); FAPESP - The State of São Paulo Research (Grant no. 06/58878-8), and IDRC - International Development Research Centre (Project no. 401666/2006-9).
} 


\section{INTRODUCTION}

For each economic or social success case in Brazil, there is a public research institute and/or a university in a supporting role. This relationship that lies behind most Brazilian products with comparative advantages in the international market was built during a long historical process of learning and accumulation of scientific knowledge and technological competencies. This process involved significant linkages between productive effort, government's policy and funding, and research and education institutions. The most notorious examples are: in health sciences, the production of serums and vaccines by Oswaldo Cruz Institute and Butantan Institute; in agrarian sciences, production and exports of soybean and other grains, cotton, cellulose and meats by firms and planters interacting with Campinas Institute of Agronomy (IAC), Federal University of Viçosa (UFV), Embrapa (Brazilian Agricultural Research Corporation), and several regional education and research institutes; in mining, materials engineering and metallurgy, production of ores and development of steels and special metal alloys by mining and steel corporations in collaboration with Federal University of Minas Gerais (UFMG); in aeronautical engineering, aircraft production by Embraer (Brazilian Aeronautics Corporation) supported by a specialized research institute - the Aeronautics Technical Center (CTA) and a specialized higher education institution - the Aeronautics Technology Institute (ITA); in geosciences, oil and gas production by Petrobras (Brazilian Oil Corporation), specially the drilling technologies for deep waters developed in interaction with Federal University of Rio de Janeiro (UFRJ), State University of Campinas (Unicamp) and many other education and research institutions all over the country.

Although incomplete, the institutions of an evolving system of innovation are important, in the Brazilian case, to support areas, sectors and products where Brazil has competences or international competitive advantages. In other words, in these successful areas, sectors and products the interactions are operating between, on the one hand, universities and public research institutes, and on the other hand, firms, farmers and society at large.

This paper falls under the heading of economic history of science and technology, as suggested by Tamás Szmrecsányi (2000), because history matters for maturing mutually reinforcing relationships between those two dimensions. Furthermore, economic history of science and technology indicates that the monetary-financial dimension should be integrated into the analysis. As this paper shows, the formation and the maturing of successful cases of interaction take time and result from long-term processes of institutional building. History also matters in a broader sense related to the major features of Brazilian system of innovation, because there is a late onset of this institutional process - the early $19^{\text {th }}$ Century. This late beginning precedes Brazilian late industrialization but has important relationships with the nature of our industrialization. That 
is why a study of economic history of science and technology helps the understanding of present day structure of Brazilian system of innovation.

Therefore, the subject of this paper is the historical roots of interactions between public research institutes, universities and firms, a key feature of a national innovation system formation. The objective of this paper is to investigate the contributions of public research institutes (PRIs) and universities, in their interactions with firms and economic agents at large, to the successful cases of Brazilian economy. Conventional wisdom seems to underestimate the role of universities and PRIs in less developed countries. This conjecture may shed new light in the interpretation of Brazilian national system of innovation (NSI): since universities and PRIs are so important for those successful cases, their late onset may be an important handicap for the evolution of Brazilian NSI. Furthermore, the problematic social context of this late onset (slavery, poverty) may further handicap the country's institutional development.

This paper is organized in six sections. The first section presents arguments from the field of economic history of science and technology, putting forward a broad agenda to inform our investigation of the historical roots of Brazilian NSI. The second section focuses the specific feature of NSI that is the subject of our investigation, reviewing the literature on interactions between firms and universities in developed nations. The third section introduces the discussion of the Brazilian institutions, presenting the late onset of NSI institutions, a first wave of institutional building (the second decade of $19^{\text {th }}$ Century). The fourth section describes the other four waves of institutional formation in Brazil. The fifth section focuses on the history of three selected successful cases, which spans from a low-tech sector (agriculture), a medium-tech sector (steel and special metal alloys) to a high-tech sector (aircraft). Sixth section concludes the paper, summing up the main findings and discussing how the unveiled pattern of long-term maturation of successful points of interaction may confront current challenges.

\section{THREE DIMENSIONS FOR AN ECONOMIC HISTORY OF SCIENCE AND TECHNOLOGY}

To develop the idea proposed by Szmrecsányi (2000), it may be necessary to deal with three dimensions, not just science and technology, but also their sources of funding, which entails some kind of analysis of monetary and financial structures. Although this subject merits a theoretical and historical discussion too vast to come within the scope of this article, a few exploratory comments may contribute here to a deeper understanding of the conjectures mentioned in the introduction: as discussed in the thrird section below, the lagging process of university and research institution building, alongside the lateness of Brazilian industrialization, also combine with the backwardness 
arising from the relatively recent creation of monetary and financial institutions in Brazil.

One of the most striking elements in world history is the coincidence, correlation or geographical juxtaposition between scientific and technological leadership and the leading region's position in terms of accumulated monetary and financial resources. However, care is of course required to avoid mechanistic associations and develop appropriate mediations and qualifications.

On an initial level, the vast historical panel elaborated by Braudel (1979; 1986) provides a secure introduction to this articulation. Braudel argues for the existence of multiple "world-economies", each with its own hierarchy and center. In the third volume of Civilization and Capitalism (entitled "The Perspective of the World"), Braudel traces the development of the European world-economy and the "world-cities" that successively ruled it: Venice (1378-1498), Genoa (1557-1627), Amsterdam (1585-1773), and London (1773-). Albeit outside the scope of his book (which stops at 1800), on many occasions he suggests how the sequence continues, with New York taking London's place in the 1920s.

The relations between these three dimensions can be inferred from a topic in the exposition of G. Arrighi, who identifies an analogy between the Italian and Dutch patterns, in the shape of "surplus capital utilization for investment in the conspicuous consumption of cultural products through the patronage of the arts and other intellectual pursuits”. According to Arrighi (1994, p. 139), "just as fifteenth-century Venice and Florence had been the centers of the High Renaissance, so early seventeenth-century Amsterdam became the center of the transition from the 'climate of the Renaissance', which had pervaded Europe in the preceding two centuries, to the 'climate of the Enlightenment', which was to pervade Europe in the next century and a half".

On a second level of analysis, it is possible to identify in the work of a historian of technology with the quality of J. Mokyr fairly early signs of linkages between universities and important economic activities. During the Renaissance, a period of history during which economic and financial hegemony was located in the Italian city-states, Mokyr highlights as one of the achievements of science and technology the onset of the application of mathematics to engineering. Among other applications, notes Mokyr (1990, p. 74), "[i]n the fifteenth century, Italian mathematicians showed how navigation could be aided by mathematics and Venice created a university chair of mathematics devoted to navigation".

Along the same lines, Freeman (1999, pp. 150-151), in an interesting historical overview of innovation systems, refers to the industrial and technological leadership of Venice (stressing its leadership in finance) and notes that important institutions were created in the Italian city-states, including the first universities and the first system of patents (Venice, in 1474).

On a third level of analysis, it is possible to identify this three-dimensional articulation by focusing on a key individual in the scientific revolution. Galileo 
was supported among others by the Medici, the leading bankers during that period. Galileo produced horoscopes for the Medici (Reale et al., 1986, vol. II, p. 199). ${ }^{1}$ He studied and researched in Padua, Venice and Florence. His skill in instrumentation enabled him to develop a powerful telescope; indeed, he supplemented his salary as professor of mathematics at the University of Padua by making and repairing scientific instruments (Mokyr, 1990, p. 73). Moreover, the technical means to produce special lenses were available in the city where he lived, then an important glass manufacturing center (Ravetz, 1990, p. 210). In an account of the improvements introduced into mining during and after the Renaissance, Mokyr locates demands presented by this sector to the scientists of the time: " $[\mathrm{t}]$ he greatest minds of the seventeenth century, from Galileo to Newton, were concerned with problems of air circulation, safety, pumping, mineralogy and assaying, and the raising of coal and ore from the mines" (1990, p. 64).

On a fourth level of analysis, a more recent case suggests that it is possible to identify a link between the characteristics of finance (public and private) in the United States and the evolution of its industrial and scientific structure.

In formulating his concept of the "Long Wave from 1787 to 1842 ", Schumpeter (1939) discussed the role played by the creation of credit and other contributions peculiar to the industrialization process then under way: "[i]n the United States profits and the ad hoc creation of means of payment were obviously the main domestic sources of the 'funds' which financed industrial and other enterprises" (p. 195). ${ }^{2}$ He then suggested a role for the daring banking practices of the period: "[i]t was the financing of innovation by credit creation - the only method available, as we have seen in the course of our theoretical argument, in the absence of sufficient results of previous evolution - which is at the bottom of that 'reckless banking'. This undoubtedly sheds a different light upon it. Those banks filled their function sometimes dishonestly and even criminally, but they filled a function which can be distinguished from their dishonesty or criminality" (p. 197).

As for public finance, a number of changes made to the U.S. financial system during the New Deal (when the U.S. was consolidating its world economic and financial leadership) can be considered a precondition for the architecture of the innovation system built during and after World War II. The strengthening of public finance through the fiscal and tax-raising hegemony of the central government certainly created one of the foundations for the significant federal public spending on R\&D that was to distinguish the U.S. in the 1950s and 1960s, especially for basic science (Nelson \& Wright, 1992).

In sum, addressing all three dimensions (money-finance, science, and tech-

\footnotetext{
${ }^{1}$ When Galileo discovered Jupiter's moons, he originally named them Cosmica Sydera in honor of Cosimo de' Medici. He later opted for Medicea Sydera, honoring all four Medici brothers.

${ }^{2}$ For a discussion of monetary innovation in the United States, see Sylla (1982).
} 
nology) is most important in the economic history of science and technology. Once again, it is necessary to allude to Braudel, who explores the relations between money and technique $(1986$, p. 81$)$ and emphatically notes the role of finance in the English industrial revolution.

\section{HISTORICAL ROOTS OF UNIVERSITY-FIRMS INTERACTION IN DEVELOPED INNOVATION SYSTEMS}

The notion of national systems of innovation derives from the evolutionist or neo-Schumpeterian approach: it expresses the complex institutional arrangement that drives technological progress and by so doing determines the wealth of nations (Freeman, 1995). The NSI concept was developed by scholars who consider history an important element (Freeman, Nelson and Rosenberg, among others). Freeman (1995), for example, locates and discusses the emergence and historical development of specialized research and development $(\mathrm{R} \& \mathrm{D})$ activities, an institutional innovation introduced into Germany in 1870: this argument presented by Freeman can be considered a suggestion for a research agenda in which history is decisive.

The development of an economic history of science and technology, therefore, would contribute a great deal to our understanding of the historical roots of innovation systems. This theoretical dialogue is one of the motivations for the present article.

To some extent all the most important research into innovation systems takes into account the historical roots of the process of building the relevant institutions. The collection of essays edited by Richard Nelson (1993) is an excellent example. All 16 studies of experiences in different countries include detailed descriptions and analysis of the origins and historical development of the institutions that make up the various innovation systems concerned. These case studies, particularly those on the U.S., Japan, Germany, Sweden and Denmark, provide a wealth of examples of persistent traditions, path dependence and evolutionary processes grounded in historically relevant efforts. As a result it is not hard to see the relevance of assessing the history of how the institutions that make up these systems, especially research institutions, universities and firms, have been built.

Unfortunately one of the main weaknesses of the evolutionist approach is precisely its failure to examine in depth how monetary and financial systems are linked with the construction of innovation systems. In a critical review of the literature, O'Sullivan (2004) highlights this significant lacuna in innovation economics and proposes a dialogue between researchers in this field and financial historians to fill the gap.

Aware of this important limitation, we can move on and ask what the literature has to say about the interactions between science and technology in well-developed national systems of innovation (NSIs). 
Nelson \& Rosenberg (1993, pp. 5-9) point to the intertwining of science and technology as a key feature of NSIs. They sum up the complex interactions between these two dimensions by saying that science is both a "leader and follower" of technological progress. Evidence of this dual role can be drawn from the literature.

Rosenberg (1982) presents the role of technology as: (1) a source of questions and problems for scientific endeavors; (2) an "enormous repository of empirical knowledge to be scrutinized and evaluated by scientists" (p. 144); (3) a contribution to formulation of the "subsequent agenda for science" (p. 147); and (4) a source of instruments and research equipment etc. Rosenberg concludes that "powerful economic impulses are shaping, directing and constraining the scientific enterprise" (p. 159).

Looking now at the flow in the opposite direction, Klevorick et al. (1995) present empirical evidence about the role of universities and science as an important source of "technological opportunities" for industrial innovation. Their study shows how different industrial sectors rank the relative importance of universities and science to their innovative capabilities. ${ }^{3}$

Rosenberg (1991) asks "why firms do basic research" and suggests it is an "entry ticket to a network of information". This point relates to the discussion in Cohen \& Levinthal (1989) about the two sides of R\&D, innovation and learning, stressing the importance of investment as a way to develop "absorptive capability".

Narin et al. (1997) find empirical evidence for the "increasing linkage" between science financed by the public sector and industry in the U.S. A recent OECD study describes the "intensification of science-industry relations in the knowledge economy", stressing that "links with science are more important than in the past" (OECD, 2002, p. 16).

Finally, Rosenberg (2000) suggests U.S. universities differ from those of other (developed) countries "in the greater speed and greater extent of their response to changing economic circumstances" (p. 36). He notes five distinctive features of U.S. universities: (1) the ability to respond to the economic needs of society ("economic responsiveness"); (2) a high degree of decentralization; (3) close connectedness between universities as well as intense competition (for resources, especially financial support); (4) the size of the university system ("its great size, in contrast to any of the European countries, is important because it has made it possible to maintain a high degree of specialization and diversity within a large system", p. 41); and (5) a unique synthesis of advanced research with graduate and professional education (p. 42). Rosenberg's analysis helps show the importance of the size of a university system in en-

\footnotetext{
${ }^{3}$ Klevorick et al. show why firms monitor and follow developments in the universities. Significant knowledge streams flow from scientific institutions to the industrial sector, particularly high-tech industries.
} 
abling it to respond quickly to economic requirements, as may perhaps be more clearly presented in Klevorick et al. (1995), Narin et al. (1997) and Cohen et al. (2002).

These studies underscore the relevance of these two dimensions of innovative activities, stressing the division of labor between them, supporting an understanding of the strong and mutual feedback between science and technology in developed countries, and indicating an intensification of these linkages. Thus the literature suggests that these relationships need to function for modern economic growth to be feasible.

These studies focus strongly on the case of the United States. It is not difficult to show how the institutions and dynamics of interaction have been built up, as discussed in the above-mentioned texts. Work by such researchers as Rosenberg (1972; 2000), Nelson \& Wright (1992) and Nelson \& Rosenberg (1994) describes important aspects for an understanding of this long construction process.

The argument of this paper can now be formulated more specifically: A long historical process is required to build these linkages and interactions. At least five elements (which depend on investment and time for development and maturation) can be indicated: (1) preparation of the monetary and financial arrangements to make feasible the creation and functioning of universities/research institutions and firms, among other elements; (2) construction of the relevant institutions (universities, research institutions, firms, and their R\&D laboratories); (3) construction of mechanisms to enable these two dimensions to interact (research problems, challenges etc. that induce at least one of the two sides to seek out the other and attempt to establish a dialogue); (4) development of interactions between the two dimensions (learning processes, trial and error etc); and (5) consolidation and development of these interactions, involving an explicit recognition of the role played by time to build mutually reinforcing relationships (positive feedback) between research institutions/universities and firms (as could be derived from the literature reviewed above).

\section{THE LATE ONSET OF INSTITUTION BUILDING IN BRAZIL ${ }^{4}$}

A preliminary comparison between Brazil and the United States at the time of independence is enlightening: in 1822, with a population of 4.7 million, Brazil had no universities (Cunha, 1980), while in 1776, with 2.5 million

\footnotetext{
${ }^{4}$ This and the next sections aim at presenting a historical overview of the country's institution building in higher education and science and technology, highlighting major trends, institutions and knowledge areas. No attempt was made to cover all higher education and research institutions either at national or regional levels.
} 
inhabitants, the U.S. had nine universities (Maddison, 2001). ${ }^{5}$ Even in comparison with other Latin American countries, Brazil made a very late start on setting up universities. According to Schwartzman (1979, p. 54), "in institutional terms science in Brazil lagged far behind science in Spanish America until the second half of the eighteenth century [...] Fearing the establishment in Brazil of institutions that could rival those of Portugal, the Crown prevented the creation of a university [...]".

Although several medical, law and other schools of higher education were founded after 1808, when the Portuguese Court moved to Rio de Janeiro, no attempts to set up universities were made until the 1920s and, according to the literature on the formation of the Brazilian scientific community, the first full-fledged university created in Brazil was the University of São Paulo (USP), founded in 1934 (Schwartzman, 1979), by which time the population had passed the 30 million mark. The universities founded in the 1920s were named by Cunha (1980) as "transient universities", as for example the University of Minas Gerais and the University of Rio de Janeiro. ${ }^{6}$ Cunha's book is appropriately entitled Universidade Temporã ("The Latecomer University").

These latecomer universities, however, resulted from a process of institution-building that had begun a long time ago. For example, when USP was founded it incorporated the Polytechnic (founded 1894), the School of Pharmacy (1898), the School of Medicine \& Surgery (1912), the Institute of Veterinary Medicine (1919), and the Biological Institute (1924), among others.

At the turn of the century there were "only six institutions in connection with which one could speak of a scientific spirit and a taste for experimentation, and only one of those could be considered directly part of the university sphere". ${ }^{7}$ One of the characteristics of the science "that was institutionalized" in early twentieth-century Brazil was its location "outside the higher education system" (Schwartzman, 1979, p. 136).

If the creation of universities in Brazil began at the earliest in the 1920s, when did scientific research begin, given that it was conducted "outside the higher education system"? Until the late nineteenth century there were some scientific research activities in mineralogy, chemistry, natural sciences, agrono-

\footnotetext{
${ }^{5}$ To emphasize the importance of universities to development processes, it is worth comparing Germany in the 1870s, with 16 universities, and England, with only five (Blackbourn, 2003, p. 207). The history of the late nineteenth century shows Germany overtaking England in industrial, technological and scientific terms.

${ }^{6}$ According to Schwartzman (1979, p. 418), while the creation of the University of Rio de Janeiro in 1920 merged the Medical School, Polytechnic and Law School, "it changed practically nothing in the way the schools functioned".

${ }^{7}$ (Schwartzman, 1979, p. 139). The institutions in question were: the Paraense Museum, the Campinas Institute of Agronomy (IAC), the Paulista Museum, the Botanical Gardens of Rio de Janeiro, the Manguinhos (Oswaldo Cruz) Institute, and the Bahia Medical School.
} 
my, and zoology, as well as studies of bacteriological and microbiological problems, but they were limited in nature and sparsely distributed in institutions such as museums ${ }^{8}$ and research institutions. ${ }^{9}$ However, a major step in Brazilian scientific history, specifically in health sciences, was the creation of the Manguinhos Institute (later Oswaldo Cruz Institute) in 1900, with Dr. Oswaldo Cruz as its key personage. Cruz was a graduate of the Rio de Janeiro Medical School and studied at the Pasteur Institute in Paris from 1896 to 1899 (Stepan, 1976, pp. 69-73).

The school from which Cruz won his degree in medicine was founded in 1808, after King João VI came to Brazil. The arrival of the Portuguese Court led to significant changes including the creation of institutions such as anatomy and surgery courses in Rio de Janeiro and Salvador, the Botanical Gardens (1808), and the Military Academy (1810), which implicitly taught engineering (Cunha, 1980; Schwartzman, 1979). According to Cunha (1980, p. 69), "restructuring and expansion of higher education in Brazil after 1808 moved the study of mathematics, physics, biology and mineralogy out of philosophy courses, controlled by the Church, and into medical courses and the Military Academy, and much later to the Polytechnic when it split off from the latter".

The creation of these institutions between 1808 and 1810 can be considered the beginning of systematic efforts to create research and education institutions in Brazil. It is worth stressing the long gap in time between the creation of these institutions and that of the first universities: more than a century elapsed between one and the other. This explains the phrase coined by Schwartzman $(1979$, p. 81), who says science and higher education "vegetated" in the nineteenth century in Brazil. Thus, the onset of the creation of science and technology institutions was not only late but also limited, since science and higher education merely vegetated during the nineteenth century, not to mention the fact that they were entirely separate from the rest of the nation's cultural and social life, although as discussed in the next section there was to be a second wave before the century was out.

This late onset was closely related to economic stagnation and to Brazil's colonial status until $1808,{ }^{10}$ with the (perhaps consequent) absence of mone-

\footnotetext{
${ }^{8}$ Particularly the Imperial Museum (1818), later renamed the National Museum, the Paraense Museum (founded in 1866 as Archeological \& Ethnographic Museum of the Philomathic Society of Pará, later renamed the Goeldi Museum), and the Paulista Museum (1893).

${ }^{9}$ Such as the Campinas Institute of Agronomy (IAC, 1887), the São Paulo Vaccinogenic Institute (1892), the São Paulo Bacteriological Institute (1893), and the Butantan Serum Therapy Institute (1899). See Schwartzman (1979: Appendix 1 - Timeline of Brazilian Science, 1500-1945, by Tjerk Guus Franken); and Sanjad (2006) specifically on the Goeldi Museum.

${ }^{10}$ The colonial period to 1808 can be considered a long epoch during which Brazil's autonomous development remained blocked. The colonial system was a lasting obstacle to scientific accumulation for the future nation. Paula (1988) and Novais (1979) show how the mechanisms of colonial domination
} 
tary institutions. According to Peláez \& Suzigan (1976, p. 38), until the arrival of João VI monetary institutions "did not exist in Brazil, and there was nothing that could be called a paper currency". Gold, silver and copper had hitherto comprised the only means of payment circulating in Brazil.

The situation in 1808 can be characterized as a combination of restrictions imposed by the metropolis on manufacturing in the colony, a lack of higher education institutions, and a lack of monetary institutions. In other words, until 1808 the triad discussed in the first section (money, science and technology) was practically non-existent in Brazil. After the arrival of João VI, institutions relating to the triad were created (Banco do Brasil, higher education institutions) or permitted (repeal of the ban on manufacturing).

Finally, besides being late and limited, the onset of institution building took place under adverse conditions, given the presence of slavery. Freyre (1990) discusses the relations between "slaves, animals and machines" in his book on Brazil during the sojourn of João VI (Chapter 10), describing how slavery contributed to the persistence of human traction in Brazil at a time when Western Europe and the U.S. were embarking on the transition from draft animals to steam traction (p. 527). Slavery was a major barrier to technical progress: "there is one great cause that prevents the adoption of machinery in abridging manual labour, as so many persons have an interest in its being performed by the slaves alone", noted an English observer cited by Freyre (1990, p. 533).

Moreover, the inequality of the colonial economy determined by slavery is a key historical reason for the polarity between "modernization and marginalization", defined by Celso Furtado (1987) as a structural feature of Brazilian economic growth and underdevelopment in general. This polarity and the "inadequacy of technology" also identified by Furtado help explain the structural persistence of inequality in Brazil and suggest questions for evaluating their impact on science and technology (restriction of resources for and interest in the generalization of basic education and elimination of illiteracy, as well as preservation of the elitist nature of higher education, with significant consequences in terms of lack of critical mass to trigger positive feedback processes between science and technology).

Furtado's emphasis on social problems can also be seen in his argument that the success of South Korea and Taiwan owes much to social homogenization. In the Brazilian case, the modernization-marginalization polarity imposed a dynamics of growth that systematically reproduced exclusion, thus preserving and at times even intensifying social inequality.

In short, the discussion in this section shows that research and education

operated to block economic progress in general. Within this overall blockage, specific measures affected the accumulation of scientific knowledge in Brazil. To take only one emblematic example, books were not allowed freely into the colony until 1821. 
institution building in Brazil began late, was limited in scope and problematical in nature because of the adverse conditions under which it took place.

\section{DEVELOPMENT OF HIGHER EDUCATION AND RESEARCH INSTITUTIONS}

In addition to determining the late onset of the scientific accumulation process, the legacy of the colonial period includes countless problems that were to become major deficiencies and obstacles to development. The consequences of slavery have been analyzed by Sérgio Buarque de Holanda (1991, p. 25), Alfredo Bosi (1993, p. 146) and Roberto Schwarz (1991, p. 15). Holanda (pp. 50-51) shows how "intelligence [was cultivated] as an ornament" rather than as an "instrument of knowledge and action". Schwarz refers to the "misappropriation of modern ideas" in the initial period after Independence, blaming the local elite for "oligarchic appropriation of progress on the plane of ideas" (1991, p. 139). The long-term influence of these problems on the process of scientific knowledge accumulation should not be underestimated, since they prevented the emergence of a climate that would have stimulated creativity, a free exchange of views, critical thinking, and experimentation, all of which are indispensable to scientific development.

These problems help to explain the fact that, after the outburst in the creation of institutions upon the arrival of the Portuguese Court to Rio de Janeiro, only in the late Empire, between 1870 and 1900, did a second wave of institution building occur. Most of the institutions then created were research institutions dedicated to natural history, astronomy, bacteriological medicine, descriptive geosciences and traditional chemistry (Schwartzman, 1979, pp. 136-7). ${ }^{11}$ However, three important higher education institutions, which later would have a notable influence on the accumulation of scientific knowledge applied to mining, materials and metallurgical engineering, and agronomy were founded in this period: the Ouro Preto Mining School (EMOP, 1875), the São Paulo Polytechnic (1894), and the Luiz de Queiroz Higher School of Agriculture (ESALQ, 1901). ${ }^{12}$

\footnotetext{
${ }^{11}$ Some of the most notables among such research institutions then created are: the Pará Archeological \& Ethnographic Museum (1866), the Geology Commission (1875, dissolved in 1877 for lack of funds), the Experimental Physiology Laboratory, attached to the Imperial Museum (1880), the São Paulo State Geography \& Geology Commission (1886), IAC (1887), the Paulista Museum (1893), the Vaccinogenic, Bacteriological and Butantan Institutes (1892-99), the Manguinhos (Oswaldo Cruz) Institute (1900), and the São Paulo Polytechnic's Materials Testing Laboratory (1899), a precursor of the São Paulo State Technological Research Institute (IPT), officially founded in 1934. See Stepan (1976), Schwartzman (1979), and Motoyama (2004).

${ }^{12}$ The Polytechnic school would become part of USP in 1934, as mentioned above. EMOP and ESALQ will be discussed in some detail in the next section.
} 
A third wave can be identified in the period 1920-34, when initiatives to create universities culminated with the foundation of USP in 1934. This was the "latecomer university" wave. The period is described by Cunha (1980), who distinguishes between "successful universities" and "transient universities". According to Cunha, "the first long-lasting higher education institution in Brazil with the term university in its name was the University of Rio de Janeiro, founded in 1920 after many failed attempts" (p. 212). Its creation involved a merger of Rio de Janeiro's Polytechnic with its Medical School and "one of its law schools" (p. 212). However, as mentioned above, the schools concerned continued to function independently (Schwartzman, 1979, p. 418). In 1927, the "technique of organizing universities by agglutination was emulated in Minas Gerais" (Cunha, 1980, p. 213).

The creation of USP in 1934 amalgamated existing schools with the newly founded School of Philosophy, Sciences \& Letters. USP's foundation can be identified as the most important point in a broad process of endeavors, initiatives and articulations to build universities in Brazil, and as the creation of a new standard of quality which became a national benchmark from then on (Motoyama, 2004; Schwartzman, 1979). The education-research nexus was still weak, although there was already an awareness in some universities that a link had to be established. ${ }^{13}$

The fourth wave of institution building occurred in the post-war period. A national association of researchers was founded in 1948 (SBPC - Brazilian Association for the Progress of Science). The Brazilian Center for Physics Research (CBPF) was set up in 1949 and the Aeronautics Technology Institute (ITA) in 1950, with the Aeronautics Technological Center (CTA) following shortly afterward. Two important Federal government coordinating institutions were set up in 1951: the National Research Council (CNPq) and the Higher Education Staff Development Office (CAPES). In the context of the period preceding the 1964 military coup, it is also important to note the creation of the São Paulo State Research Funding Agency (Fapesp), and the University of Brasília (UnB).

A fifth wave during the period of military rule can be identified. The highlights were: (1) in higher education, the creation of state universities in São Paulo $^{14}$ and in other states, as well as the beginning of graduate courses, creating links between teaching and research activities; (2) the creation of research

\footnotetext{
${ }^{13}$ As noted by Schwartzman (1979, p. 104), in the 1930s ESALQ attempted to build closer ties between teaching and research, especially in genetics, in collaboration with IAC, which had begun a program of genetics applied to agriculture in 1928 (Schwartzman, 1979, p. 274).

${ }^{14}$ State University of Campinas (Unicamp, 1966), and State University of São Paulo (Unesp, 1976).
} 
centers in state-owned enterprises like Petrobras and Telebras, ${ }^{15}$ and the foundation of Embrapa in $1973 ;^{16}$ (3) the establishment of regulating agencies for intellectual property, ${ }^{17}$ industrial sectors (computers, steel, oil) and regional development, ${ }^{18}$ and (4) the creation of institutions and funds for science and technology (S\&T) financing, planning and policy making. In technology financing, the Technology Development Fund (Funtec) was set up in 1964 and administered by BNDES, the national development bank, which had been created in 1952. This fund gave birth to the National Technological Development \& Innovation Agency (FINEP, 1965), which was to play an important role in coordinating government funding for $\mathrm{S} \mathrm{T}^{19}$ and implementing university courses for graduates. S\&T Development Plans (PBDCT) were launched in the context of national development plans between 1972 and 1984, in an explicit attempt to create a truly national system for the development of science and technology (SNDCT). However, all these plans were only partially implemented and then abandoned in the 1980s with the advent of an acute macroeconomic crisis.

A noteworthy fact about coordinating institutions is that Brazil's Ministry of Science \& Technology (MCT) was not created until 1985, with the end of the military regime. Until the mid-1990s the MCT faced serious difficulties, as indeed did all the institutions responsible for S\&T funding and development, because of the weakness of the monetary and financial system, the third element in the triad mentioned in the first section above.

Although the monetary system grew as economic development gathered pace from the closing decades of the nineteenth century onwards, culminating in the creation of the Central Bank of Brazil in 1964, its structure evolved little. Private banks remained restricted to commercial lending. The demand for credit to finance industrial investment and S\&T began to be met only after the federal government set up development agencies for this purpose, above all BNDES and FINEP in the 1950s and 1960s respectively. Endemic inflation kept the financial system and capital market underdeveloped until the

\footnotetext{
${ }^{15}$ Petrobras (Brazilian Oil Corporation) established CENPE (Research and Development Center) to attend its own technological needs with in-house research work and links with universities and research institutions all over the country. Telebras' CPqD (Research and Development Center) reached important technological advances in the field of telecommunications in the late 1970s and early 1980s.

${ }^{16}$ It is important to note that agricultural research was well under way in the country before Embrapa's foundation (see next section).

${ }^{17}$ The Brazilian patent office, INPI (National Institute of Industrial Property), was founded in 1970.

${ }^{18}$ Following the success of SUDENE (Superintendence for the Development of the Northeast), created in 1959 and headed by Celso Furtado, other regional development agencies were created in the 1970s.

${ }^{19}$ Especially via the National Fund for Scientific \& Technological Development (FNDCT).
} 
mid-1990s, and this undoubtedly retarded still further the already lagging process of industrialization and, by extension, the process of scientific and technological development.

Summing up: (1) higher education institutions had a late development and when they did develop their characteristics were framed by historical events of Brazilian economy and society, remaining small in scale, concentrated in humanities, weakly connected with production activities; applied research was restricted to agronomy, mining/metallurgy, and health sciences. Engineering fields developed even later, and graduate courses linking teaching and research activities were introduced only from the 1960s onwards, with Federal government support; (2) specialized research institutes, on the other hand, developed relatively earlier to attend local demands mostly from agriculture and public health, and played a major role in scientific and technological development in those areas (see next section). Framing this picture, local industry demands did not stimulate S\&T development, and funding remained scarce, as briefly discussed below.

\section{IDENTIFYING SUCCESSFUL CASES OF INTERACTION}

To the belatedness and problematical nature of the process of institution building for the national innovation system must be added, also with negative connotations, the characteristics of the industrialization process, which placed limited and relatively unchallenging demands on the nation's education and research institutions. ${ }^{20}$ Unlike agriculture, whose hegemonic position in the economy and society was capable of influencing, to some extent, scientific and technological progress, manufacturing industry had little or no influence until the end of the 1920s. Being mostly a subsidiary activity to agriculture in terms of direct demand, and dependent on agricultural income to fuel domestic demand, industrialization was restricted throughout this period by the fact that demand from the hegemonic sector - and society in general - was limited. Only from the 1930s onwards did industrialization become an autonomous process focused in the domestic market. Diversification of production advanced throughout until the end of the 1970s, but technological needs were limited and mostly directed to foreign markets in the form of imports of machinery and acquisition of technology. Industry's demands on S\&T institutions, albeit more sophisticated, remained relatively unchallenging until at least the end of the 1980s, as reflected by the late evolution of production

\footnotetext{
${ }^{20}$ In his reading of the role of large enterprises in the industrialization processes of the U.S. and Germany, Chandler (1990) refers explicitly to the demands presented and met by education institutions in both countries, in contrast with Britain (for the U.S., pp. 82-83; for Germany, pp. 425-426).
} 
structure (see Chart 1). This had to do with excessive protectionism, the domination of key industries by foreign capital, lack of continuity in public policy, and recurrent macroeconomic crises. ${ }^{21}$

Chart 1:

Evolution of Brazilian Manufacturing Industry

Production Structure,1920-1990, Percentages

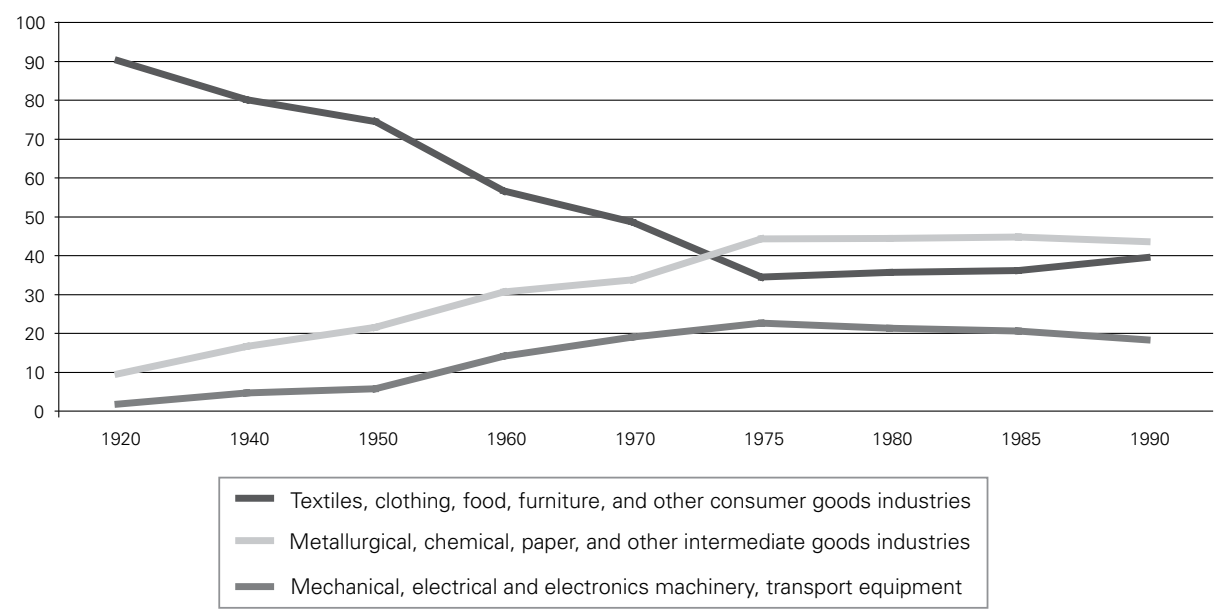

Source: Bonelli (1996: 74, Table 2.2) based on industrial censuses data.

In this environment the monetary and financial system also remained subordinated to agriculture for export, mainly to cater for its needs in terms of trade finance. Although industrialization benefited from the development of trade bill discounting, the benefits were limited because the financial system did not offer long-term credit for investment. Meanwhile, the government's position was ambivalent: it offered protection for certain industrial activities but at the same time cut budget allocations for programs designed to create capabilities in technology intensive areas. ${ }^{22}$

In sum, these characteristics determined a predominant technological pattern that presented few demands to the scientific and university system. The universities remained limited to education. The combination of teaching and research began to be systematized only in the 1960s and 1970s, with the organization of graduate programs.

\footnotetext{
${ }^{21}$ For an overview of Brazilian industrial development in the $19^{\text {th }}$ century, see Bonelli (1996).

${ }^{22}$ Schwartzman (1979, pp. 115-119) recounts an "attempt to implement chemistry" from 1919 when a private member's bill was passed to set up chemistry institutions and courses in industrial chemistry in various parts of the country. The program proceeded successfully until 1930, when the government cut off federal funding in response to economic crisis.
} 
Despite all these difficulties, linkages between the economy and higher education and research institutions did occur in a few knowledge areas. A few historical examples focusing specific products are presented in some detail below to help develop the central argument of this paper. But before that it is worth mentioning some science areas in which Brazil accumulated expertise after a long process of learning and institution building to match local needs.

Health sciences are one of the world-class knowledge areas in Brazil today, especially in biomedical research for production of serums and vaccines. Two institutions have made a vital contribution to this achievement and are now internationally recognized for the production of both scientific knowledge, disseminated via the publication of paper in international journals, and serums and vaccines. They are the Butantan Institute in São Paulo and the Manguinhos Institute in Rio de Janeiro, later renamed the Oswaldo Cruz Institute and now Fiocruz.

Those two institutions were created between the late nineteenth and early twentieth century to control the spread of epidemic tropical diseases like yellow fever and Chagas disease, as well as to combat epizootic diseases (Schwartzman, 1979, pp. 120-121). From serum and vaccine production they soon progressed to scientific research led by four of the first Brazilian scientists to acquire renown: Adolfo Lutz, Vital Brazil, Oswaldo Cruz and Carlos Chagas. Publication of scientific papers drew attention from foreign scientists, who began to take an interest in the research they reported and in working in Brazil, as was the case in the ensuing decades. An important factor that influenced this trend was international recognition for the Manguinhos Institute in 1907, when it won a gold medal as first prize at the Fourteenth International Congress of Hygiene and Demography in Berlin (Schwartzman, 1979, p. 132). The same author (p. 129) describes how Manguinhos, set up to produce serums and vaccines, was transformed under the leadership of Dr. Oswaldo Cruz into a center of education, research, technological development, innovation and biomedical service provision, a position consolidated more recently. As for Butantan, it has recently been rated the most important research institution in Brazil in terms of the mean number of citations per scientific paper published. ${ }^{23}$

Brazil's acknowledged international competitiveness in agricultural commodities and agribusiness is grounded not just in comparative advantages but also in a long process of research and education institution building in the field. The process began at the apogee of the coffee economy between the last quarter of the nineteenth century and the first three decades of the twentieth, advancing further in step with industrialization from the 1930s on.

\footnotetext{
${ }^{23}$ Study by Rodrigo Semeghini based on data from the Web of Science on citations between 2005 and 2007 of articles published in 2005 (Folha de S.Paulo, Oct. 28, 2007).
} 
During the period when coffee was the main export staple, demand from coffee growers led to the creation of a number of institutions directly and indirectly related to coffee activities starting in the late nineteenth century. These institutions played a significant role in the development of education and research in agrarian sciences during the twentieth century. The most important were IAC (1887); the São Paulo Polytechnic (1894), which offered a course in agricultural engineering; ESALQ (1901); and the Coffee Defense Service (1924), set up to combat coffee pests and diseases and precursor of the Biological Institute for Agricultural \& Animal Defense (1927), later renamed the São Paulo Biological Institute (Schwartzman, 1979, p. 422).

A nice and well documented example of the activities of those institutions, in collaboration with the productive sector, may be illustrative. In the 1920s the São Paulo State Government launched a research program to improve cotton growing in the region. The aim was to produce cotton with longer fibers, which would fetch better prices and enjoy higher demand in the international market. The program was executed by a new department dedicated to cotton, set up in 1922 at IAC, and consisted of the selection of seeds and their distribution directly to growers, in accordance with rules laid down by IAC's Cotton Section. A financial institution, the São Paulo Commodity Exchange (BMSP), was set up in 1917. Peláez (1972, pp. 114-120) describes the links between IAC, BMSP, the government, the growers and industry. BMSP sent technicians abroad for training, and "while IAC was developing new cotton fibers, BMSP prepared the market for Brazilian cotton" (p. 117). According to Peláez (1972, p. 117), "it included most of the ingredients of modern technical assistance programs: development of research centers, technology transfer, financial knowledge, specialization abroad, and market development".

The role of IAC in researching new varieties of cotton, selecting seeds and distributing them to growers had been supported by BMSP since 1919. Among other things BMSP created a Cotton Grading School in 1922 (p. 117). The positive results of this program benefited the textile industry, then the most important industry in Brazil, and encouraged more textile manufacturers to install production facilities in the state (Suzigan, 2000, p. 161).

Other cases of successful products in international markets also have historical roots, albeit less remote, involving interactions between government, research institutions and firms. In order to illustrate the main point of this paper in a more systematic way, three products which are presently competitive in international markets have been selected: soybean, steel products, and aircraft. 


\section{Soybean $^{24}$}

From its experimental introduction in Brazil (1882) until becoming the country's main agricultural export commodity, soybean went through a beautiful history with experiments to adapt its culture to Brazilian soil and climate, formation of plant-breeders and researchers, and intense interaction between science (research institutes, universities), technology (soybean growers, seed production firms, agribusinesses) and government (legislation, funding). For the sake of brevity, only the major scientific and technological achievements of this saga will be presented below.

First and foremost, the formation of Brazilian soybean plant breeders. Graduation of agronomic engineers by ESALQ began in early twentieth century, and later on by the Higher School of Agriculture and Veterinary, founded in the 1920s in Viçosa, state of Minas Gerais, later renamed Federal University of Viçosa (UFV). From those two institutions came some of the future researchers that worked with soybean experiments in the first half of the twentieth century, a few of them with a $\mathrm{PhD}$ degree from land grant colleges in the U.S.A. Zancopé \& Nasser (2005) describe five lines of varieties in which plant breeders were formed, all derived from American varieties, and four generations of breeders, starting with a master generation formed mostly by American researchers working in Brazil, followed by three generations of Brazilian breeders, with two breeders in the first, 16 in the second, and three in the third generation. The authors state that the adaptation of American varieties to the temperate climate of Rio Grande do Sul occurred between 1920 and 1940, so that soybean started to appear in that state's statistics in 1941. The experiments were conducted at agronomical research institutes (IAC and IAS - Agronomical Institute of the South, in Rio Grande do Sul), and later also at UFV.

In the 1950s the first generation of Brazilian plant breeders, working at IAC with the assistance of an American breeder, came out with new varieties (1958) considered to be the first commercially successful Brazilian varieties. This achievement showed that Brazilian agronomical researchers working with soybean had acquired scientific knowledge and technological capability to develop entirely new varieties. In fact, the following 1960 and 1970 decades witnessed the adaptation of new cultivars to the dry conditions of the Brazilian central region (Cerrado) by UFV and the newly created Embrapa (Brazilian Agricultural Research Corporation, 1973).

Other major scientific and technological achievements were: the development of varieties adapted to longer lengths of lightness; inoculation of bacteria

\footnotetext{
${ }^{24}$ This section draws extensively from a book (Zancopé \& Nasser, 2005) which analyses "the saga of Brazilian soybean" from its introduction in the country to present days. We are thankful to Evando Mirra de Paula e Silva for bringing this book to our attention.
} 
that feed nitrogen to the plant; mechanization of the farms; planting by direct-drilling; development of a seed industry, and control of soybean plagues. The following paragraphs give a succinct explanation of each one of those technological developments.

Adaptation of soybean to longer periods of light (photoperiod) started with the identification, by one of the first generation Brazilian plant breeders in 1958, of a variety that was insensitive to the photoperiod. A little later a second generation plant breeder developed a variety with a naturally long cycle, better adapted to the differences of lightness in the North and South hemispheres. The greatest achievement, however, was the discovery by a Brazilian breeder working in the U.S.A. of the recessive gene that controls the plant's sensitivity to the photoperiod. After completing his $\mathrm{PhD}$, that Brazilian breeder returned to Brazil and opened in the Embrapa branch dedicated to soybean in the state of Paraná a pioneer line of genetic research which meant Brazilian technological autonomy in genetic research of the photoperiod. With this achievement, Brazilian breeders became capable of producing cultivars adapted even to latitude zero, turning soybean a tropical plant.

Technological efforts to develop bacteria ${ }^{25}$ inoculants to reduce the need of fertilizers started in the 1930s at the IAC, but only in the 1950s did the Microbiology Section of the Rio Grande do Sul Secretary of Agriculture began to develop rhizobium colonies for large scale production. At about the same time, the Institute of Biology and Technological Research (presently known as Tecpar - Technology Institute of Paraná) in the state of Paraná, developed its own cultures of rhizobium and started to produce inoculants. Large scale commercial production of inoculants was undertaken by private firms in Rio Grande do Sul and Paraná states.

Mechanization of Brazilian soybean cultures was late because of the late development of domestic agricultural machinery production. A few national firms started to produce wheeled tractors and harvesters in the 1960s in Rio Grande do Sul, but soon some large international manufacturers built plants in Rio Grande do Sul and Paraná. However, only after the creation of a special credit line at BNDES in 1976 did mechanization advance. At present, production is fully mechanized in Brazilian soybean farms.

Direct-drilling - to plant directly on the vegetable coverage of the soil was introduced in the late 1960s in the states of São Paulo, Paraná and Rio Grande do Sul. However, it was in the Cerrado ${ }^{26}$ that direct-drilling proved to be a valuable technique. It turned the low fertility lands of Cerrado into economically viable lands (Zancopé \& Nasser, 2005, p. 194). When Cerrado lands became viable, Brazilian soybean production soared from the late 1970s onwards.

\footnotetext{
25 The scientific name of the bacterium is Bradyrhizobium japonicum. It draws nitrogen from the air and feeds it to the plant, thus reducing the need of fertilizers.

${ }^{26}$ Brazilian savannah, in the central region of the country.
} 
The first Brazilian firm in the seed industry (Agroceres) was established in 1945. It was subsequently sold to foreign capital, renationalized in the 1980s, and finally denationalized again in 1997 . Today the industry is dominated by foreign firms. More important, however, was the formation, from the late 1950s onwards, of agronomical engineers specialized in seed inspection, and the enactment in 1965 of a Brazilian seed law regulating production and commercialization.

When soybean culture spread quickly in the 1980s, its cultivation started to be stressed by plagues. The soybean division of Embrapa came to play a most important role in biological control. An example is the biological solution for the plague of the soybean-worm. In fact, solution of this case started before the foundation of Embrapa. In 1972, an agronomy student at ESALQ observed that soybean-worms were dying in an atypical way in experimental fields. The insects were sent to an insect pathologist in the U.S. who discovered that the worms had been infected by a lethal virus. After completing his graduate studies with the same pathologist in the U.S. the student returned and, already working at the soybean division of Embrapa, developed a biological insecticide. Field tests in the beginning of the 1980s proved the efficiency of the insecticide, which was finally formulated and licensed to five commercial firms in 1986 (Zancopé \& Nasser, 2005, p. 202-3).

This case shows clearly that all agents - higher education institutions, research institutes, government, agricultural producers and business firms interacted for a long period before soybean became a major export commodity. Chart 2 gives a summary picture of the soybean saga in Brazil.

Chart 2: Brazilian Soybean Cultivated Area, 1952-2006 (thousand hectares) and Exports, 1989-2008 (US\$ million, FOB)

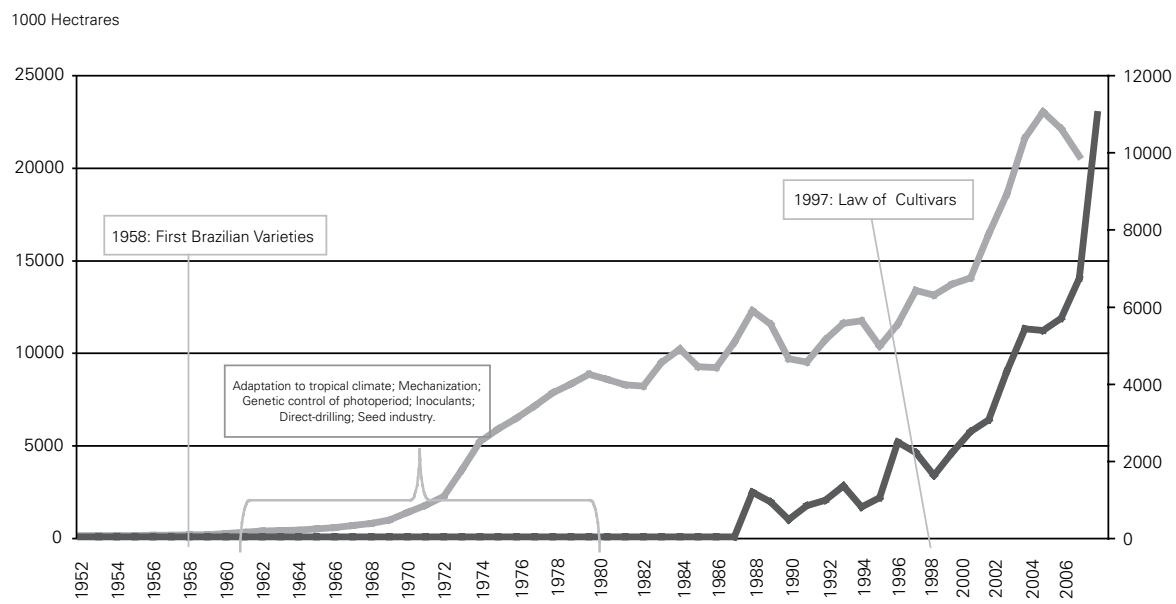

Cultivated area $\quad$ Exports 


\section{Steel products}

The first business ventures in iron production in Brazil date from the early nineteenth century, but it was not until the Ouro Preto School of Mines (EMOP) was founded that production began to increase in scale. The creation of EMOP was inspired by Emperor Pedro II's 1872 visit to the Nancy School of Mines, which he used as a model, and by his contact with Auguste Dubrée, director of the Paris School of Mines, whom he invited to head the future school in Brazil. Unveiled in 1876, EMOP exerted growing influence by training geologists, mining engineers and metallurgical engineers. Between the late nineteenth and early twentieth century, these professionals contributed to the creation of geographical and geological institutions and the mapping of iron ore reserves in Brazil. Their studies and research located and measured large reserves of high-content iron ore, and in 1910 their discoveries were presented at an international conference in Stockholm, attracting foreign companies to develop the reserves (Schwartzman, 1979, p. Appendix; Suzigan, 2000, pp. 274-75). Several projects bore fruit, giving rise to the first steel mills in Brazil in the 1920s. But the decisive boost was creation of CSN (National Steel Corporation) and Vale (Vale do Rio Doce Corporation) during World War II, followed by public policy to accelerate industrialization in the post-war years.

However, one of the most important factors that explain the current success of Brazil's mining and steel industries is the rich experience of interaction between firms and the Department of Metallurgical \& Materials Engineering at the Federal University of Minas Gerais (UFMG) ${ }^{27}$ After creation of a graduate course in metallurgical and materials engineering by UFMG in 1973, its researchers discovered the industry's difficulties with imported technology and took the initiative of proposing collaboration with firms to diagnose the problems and offer solutions. The collaboration, funded by FINEP, started with the creation of technological extension courses and was later extended to include graduate programs run jointly by firms and the university. Between 1975 and 2006 the department awarded 256 master's degrees in metallurgical engineering to employees of 36 firms, and $20 \mathrm{PhD}$ degrees to employees of ten firms, all in mining and steel production. Several of the master's dissertations and doctoral theses contributed important knowledge motivated by the search for solutions to concrete problems faced by firms, generating patents and technological innovations in processes and products. Among the technological problems solved are: development of steel plates that harden in the process of baking (bake-hardenability), then dominated by Japanese steel firms; thermal treatment of steel plates in the continuous rolling mill; development of materials with a greater resistance to use by substituting niobium for molybdenum;

\footnotetext{
${ }^{27}$ For a detailed and elegant description of this experience by one of its protagonists, Evando Mirra de Paula e Silva, see Paula e Silva (2007).
} 
development of electrical and magnetic steels; development of stainless steel leagues for ethanol-fueled engines; development of metals which are sensitive to light, and development of colored stainless steels. ${ }^{28}$

Among the firms that interacted are those which are today the most competitive in international markets: Vale (mining), Acesita (special steel), CSN, Usiminas, Cosipa and Açominas (steel). Production and exports soared from the late 1970s and Brazil is today one of the largest producers and exporters of ore and steel in the world (see Chart 3).

Chart 3: Brazilian Steel Industry Exports, 1974-2007 (US\$ billion, current prices)

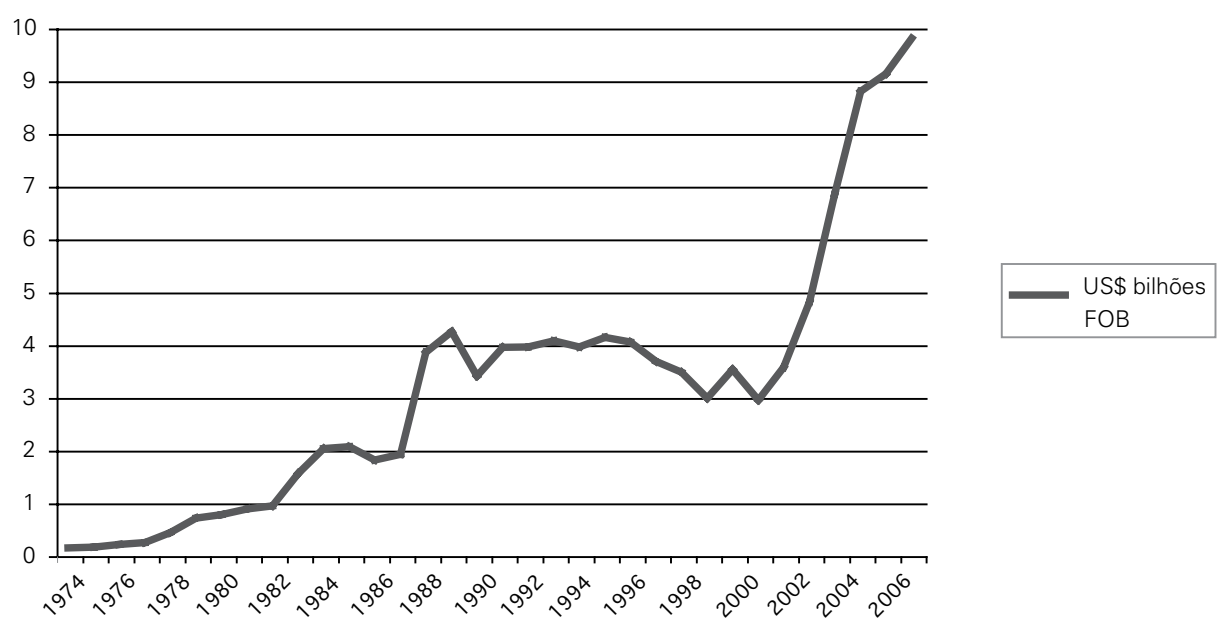

Source: Authors' elaboration based on official Brazilian foreign trade data available at IpeaData (www.ipea.gov.br).

In addition to concrete results for the firms, this program of university-firms collaboration clearly demonstrates the importance of linking graduate courses to research; proves that teaching activities can also benefit from collaboration with firms; and offers evidence that interactions can be prolonged indefinitely by the formation of interactive networks of researchers in firms and universities.

\section{Aircraft}

The position enjoyed today by Embraer (Brazilian Aeronautics Corporation) as one of the world's leading aircraft manufacturers results from a long history of efforts involving government, firms, and research and education institutions. Since the 1930s the armed services and civilian experts alike had tried to persuade the government that Brazil needed an aeronautical industry

\footnotetext{
${ }^{28}$ Paula e Silva (2007) presents several concrete cases that illustrate the brilliant results achieved in technically elegant detail.
} 
as part of the industrialization process and national defense strategy (Forjaz, 2005, pp. 281-282).

The first step, taken in the 1940s in the context of World War II, was creation of the Air Force Ministry to merge military aviation subordinated to the army and naval aviation into a single force. The project was designed from the start to assure mastery of aeronautical technology. As a result, well before aircraft production, an aeronautical engineering course was created at ITA and CTA was set up as a research center. Both were planned in late 1945. ITA began operating in 1948 on the premises of the Institute of Military Engineering (Rio de Janeiro) and was formally created in early 1950, when it was installed at São José dos Campos. CTA was set up shortly afterwards, with ITA formally subordinated to it (Forjaz, 2005, p. 290).

Thus the training of aeronautical engineers and mastery of aeronautical technology preceded creation of the industry. To assure a standard of excellence in these activities, agreements were signed with foreign institutions that sent scientists, researchers and professors while accepting Brazilian graduate students to study abroad. In 1961 ITA began its own graduate course, and a prototype of the Bandeirante aircraft designed and built at CTA flew in 1968. Embraer was founded as a state company in 1969 and privatized in 1994.

Chart 4: Brazilian Exports of Aircraft, 1996-1998 (US\$ billion, current prices)

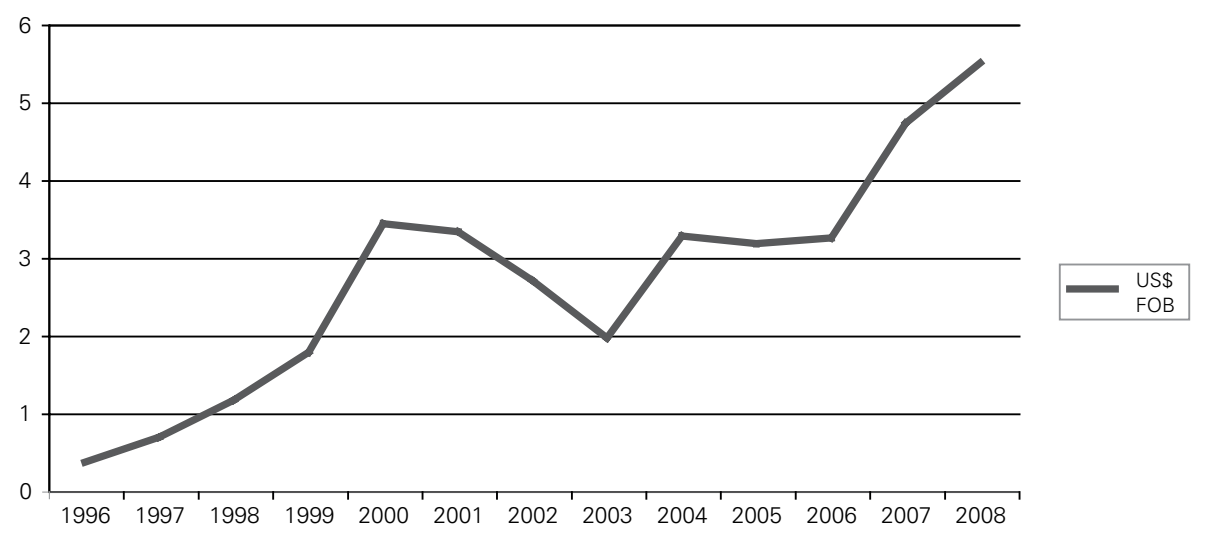

Source: Authors' elaboration based on official Brazilian foreign trade data available at IpeaData (www.ipea.gov.br).

This was a pioneering experience in linkages between education, research and industry, with flows of personnel, researchers and students between Brazil and abroad contributing decisively to the industry's successful implementation. This long standing collaboration led the company to occupy a niche in the international aircraft manufacturing industry, becoming one of Brazil's largest export firms (see Chart 4).

Analyzing this case, Forjaz (2005, p. 292) stresses that "native S\&T development requires a relatively long maturation period and thus requires per- 
sistence and confidence in the future. However, it enables a domestic industry to offer the products that markets want and that are capable of surviving in a fiercely competitive international market".

Other cases could also be discussed, but the examples given will suffice to provide an overview of the demands presented by the economy and society during some of the "institution-building waves" we have identified. More cases are described in Furtado (1982) who, in discussing the tensions created by the industrialization process under Vargas in the 1930s, mentions the contribution by IPT (Technological Research Institute) to development of the cement industry (p. 21) and metallurgical industry (p. 23). Even the creation of USP can be seen as linked to the industrialization drive beginning in the 1920s, based on certain highly utilitarian positions advocated in debates on the future university (Schwartzman, 1979, p. 192).

In other words, the examples of successful cases do indeed indicate the importance of long-term construction involving systematic efforts that persist over time. They contribute to an explanation of the historical roots of the scientific specializations that Brazil has today: medicine/health sciences, agriculture, materials/metallurgy engineering, and aeronautics are major knowledge areas and/or scientific disciplines in Brazil. This brief overview contributes to an understanding of the long construction process that has taken place in these areas.

\section{CONCLUSION}

This paper has shown four inter-related topics that enlighten the nature of a key component of Brazilian NSI: the interactions between universities, public research institutions and firms. First, there is an important role of public research institutes and universities in successful cases of Brazilian economy. Conventional wisdom usually underestimates this important role. Second, history of science and technology institutions shows a long-term process of formation of these public research institutes and/or higher education institutions and their interactions with industrial firms, agricultural product growers or society. This long-term formation process may have important implications for present day public policies. Third, this long-term formation process has led to points of science-technology interaction that may be identified today by conventional tools of the economics of innovation. In other words, in the Brazilian case, contemporary successful cases of interaction have long-term historical roots. Fourth, as the economic history of science and technology suggests, the inclusion of the monetary-financial dimension in this analysis is worthwhile, since it has been possible to show previous or simultaneous changes in funding and financing conditions related to these long-term processes.

These topics put forward an important research issue: why are successful 
cases of interaction between universities, public research institutions and firms so limited in the Brazilian case? One topic in answering this question is the late onset of Brazilian institutions that constitute a system of innovation. Furthermore, the $19^{\text {th }}$ century institutional context that embedded this institutional late onset is a handicap: the presence of slavery, the colonial nature of the country, just to indicate some important topics. This institutional context left its marks in the later process: the result is a long term path-dependent process, a process that incorporates and reproduces over time the income inequality of that period. Celso Furtado (1987) calls it the polarization "modernization-marginalization". This polarization, as it reproduces itself over time, blocks a broader spread of these positive feedbacks between research institutions and economic agents.

Finally, there is an important challenge. One of the main features of capitalist development has been the increasing scientific content of technologies. For countries like Brazil, that has a catching up process as a goal, the interactions between universities and firms are even more important from now on. There is a lot of institutional building that has to be done now - a truly sixth wave of institutional formation. But, as this paper has shown, time matters to the formation of the necessary institutions and for the maturing of their interactions with firms and society. Therefore, public policies must be institutionally creative to handle these challenges.

Besides unblocking the lock-in represented by the polarization "modernization-marginalization", there is a two-sided process to be triggered. On the one hand, there is no time to waste, so it is now that must be defined bold investments combining the development of the scientific side with the industrial dimension. On the other hand, this process should be telescoped - there are lessons to be learned from the South Korean and Taiwanese catching up processes, which telescoped the maturation of important institutions of their innovation system.

\section{REFERENCES}

ARRIGHI, G. (1994) O Longo Século XX: Dinheiro, Poder e as Origens do Nosso Tempo. Rio de Janeiro/São Paulo: Contraponto/Unesp.

BONELLI, R. (1996) Ensaios sobre Política Econômica e Industrialização no Brasil. Rio de Janeiro: SENAI.

BOSI, A. (1993) Dialética da Colonização. São Paulo: Companhia das Letras.

BRAUDEL, F. (1979) Civilização material, economia e capitalismo - séculos XV-XVIII.: Volume 2 — Os jogos das trocas. São Paulo: Martins Fontes (1996).

BRAUDEL, F. (1986) Civilização material, economia e capitalismo - séculos XV-XVIII.: Volume 3 - O tempo do mundo. São Paulo: Martins Fontes (1996).

CARVAlHo, J. M. (2002) A Escola de Minas de Ouro Preto: O Peso da Glória. Belo Horizonte: Editora da UFMG, $2^{\mathrm{a}}$. edição.

CHANDLER JR., A. (1990) Scale and Scope: The Dynamics of Industrial Capitalism. Harvard: Belknap. 
COHEN, W., NELSON, R.; WALSH, J. (2002) "Links and impacts: the influence of public R\&D on industrial research", Management Science, 48 (1): 1-23.

COHEN, W.; LEVINTHAL, D. (1989) "Innovation and learning: the two faces of R\&D", The Economic Journal, 99 (397): 569-596.

CUNHA, L. A. (1980) A Universidade Temporã. Rio de Janeiro: Francisco Alves.

FORJAZ, M. C. S. (2005) "As origens da Embraer", Tempo Social, Revista de Sociologia da USP, v. 17: 281-298.

FREEMAN, C. (1995) “The "National System of Innovation" in historical perspective", Cambridge Journal of Economics, v. 19 (1).

FREEMAN, C. (1999) "Innovation systems: city-state, national, continental and sub-regional", in CASSIOLATO, J.; LASTRES, H. Globalização e Inovação Localizada. Brasília: IBICT: 109-167.

FREYRE, G. (1990) Sobrados e Mucambos. Rio de Janeiro: Record (12a . edição, 2000).

FURTADO, C. (1982) Análise do "Modelo" Brasileiro. Rio de Janeiro: Civilização Brasileira (8ª Edição, 1986).

FURTADO, C. (1987) "Underdevelopment: to conform or to reform” in MEIER, G. (ed) Pioneers of Development. Second Series. Oxford: Oxford University/World Bank.

HOLANDA, S. B. (1991) Raizes do Brasil. Rio de Janeiro: José Olympio (23a edição).

KLEVORICK, A.; LEVIN, R.; NELSON, R.; WINTER, S. (1995) "On the sources and significance of inter-industry differences in technological opportunities”, Research Policy, v. 24: 185-205.

MADDISON, A. (2001) The World Economy: A Millennial Perspective. Paris: OECD.

MOKYR, J. (1990) The Lever of Riches: Technological Creativity and Economic Progress. Oxford: Oxford University Press.

MOTOYAMA, S., org. (2004) Prelúdio para uma História: Ciência e Tecnologia no Brasil. São Paulo: Edusp/Fapesp.

NARIN, F.; HAMILTON, K. S.; OLIVASTRO, D. (1997) “The increasing linkage between U.S. technology and public science”, Research Policy, 26 (3): 317-330.

NELSON, R., ed. (1993) National Innovation Systems: A Comparative Analysis. New York, Oxford: Oxford University Press.

NELSON, R.; ROSENBERG, N. (1993) “Technical innovation and national systems", in Nelson (1993: 3-21).

NELSON, R.; ROSENBERG, N. (1994) “American universities and technical advance” Research Policy, v. 23: 323-348.

NELSON, R.; WRIGHT, G. (1992) "The rise and fall of American technological leadership: the postwar era in historical perspective", Journal of Economic Literature, vol. 30, December.

NOVAIS, F. (1979) Portugal e Brasil na Crise do Antigo Sistema Colonial (1777-1808). São Paulo: HUCITEC.

O'SULLIVAN, M. (2004) "Finance and innovation", in FAGERBERG, J.; MOWERY, D.; NELSON, R. Oxford Handbook on Innovation. Oxford: Oxford University Press.

OECD (2002) Benchmarking industry-science relationships. Paris: OECD.

PAUlA, J. A. (1988) Prometeu no Sertão: Economia e Sociedade na Capitania das Minas dos Matos Gerais. São Paulo: USP/Faculdade de Filosofia, Ciências e Letras (Tese de Doutorado em História).

PAULA E SILVA, E. M. (2007) “A experiência da colaboração do departamento de engenharia metalúrgica e de materiais da UFMG com empresas: Lições para a Lei da Inovação", Revista Brasileira de Inovação, 6 (2): 433-459.

PELÁEZ, C. (1972) História da Industrialização Brasileira: Crítica à Teoria Estruturalista no Brasil. Rio de Janeiro: APEC.

PELÁEZ, C. M.; SUZIGAN, W. (1976) História Monetária do Brasil: Análise da Política, Comportamento e Instituições Monetárias. Rio de Janeiro: IPEA.

RAVETZ, J. R. (1990) "The Copernican revolution", in OLBY, R. C. Companion to the history of modern science. London: Routledge, pp. 201-216. 
REAlE, G.; ANTISERI, D. (1986) História da Filosofia. São Paulo: Paulus (1990), volume II: $185-322$.

ROSENBERG, N. 1972. Technology and American economic growth. Armonk: M. E. Sharpe.

ROSENBERG, N. (1982) Inside the Black Box: Technology and Economics. Cambridge: Cambridge University Press.

ROSENBERG, N. (1991) "Why do firms do basic research (with their money)?" Research Policy, v.19: $165-174$.

ROSENBERG, N. (2000) Schumpeter and the Endogeneity of Technology: Some American Perspectives. London: Routledge.

SANJAD, N. (2006) "Emílio Goeldi (1859-1917) e a institucionalização das ciências naturais na Amazônia”, Revista Brasileira de Inovação, 5 (2): 455-477.

SCHUMPETER, J. (1939) Business Cycles: A Theoretical, Historical and Statistical Analysis of the Capitalist Process. Philadelphia: Porcupine, 1989 edition.

SCHWARTZMAN, S. (1979) Formação da Comunidade Científica no Brasil. São Paulo: Nacional.

SCHWARZ, R. (1991) Um Mestre na Periferia do Capitalismo: Machado de Assis. São Paulo: Duas Cidades, 2 a edição.

STEPAN, N. (1976) Beginnings of Brazilian Science: Osvaldo Cruz, Medical Research and Policy, 1890-1920. New York: Science History Publications.

SUZIGAN, W. (2000) Indústria Brasileira: Origem e Desenvolvimento. São Paulo: Hucitec.

SYLLA, R. (1982) "Monetary innovation in América", Journal of Economic History, v. XLII (1): 21-30.

SZMRECSÁNYI, T. (2000) "Por uma história econômica da ciência e da tecnologia", Economia Aplicada, v. 4 (2): 399-407.

ZANCOPÉ, G. J.; NASSER, J. M. (2005) O Brasil que Deu Certo: A Saga da Soja Brasileira. Curitiba: Tríade. 